\author{
Dr. sc. Miodrag Mićović, \\ redoviti profesor Pravnog fakulteta Univerziteta u Kragujevcu
}

\title{
PREDUZETNICI U SPORTU
}

UDK: $347.71: 796$

DOI: $10.31141 /$ zrpfs.2021.58.139.77

Pregledni rad

Primljeno: 20. listopada 2020.

Pored pravnih lica nosioci sportskih delatnosti mogu da budu i fizička lica, za koja se kaže da su preduzetnici u sportu. S obzirom da se u pojedinim propisima i praksi za označenje ovih lica koriste i drugi termini, u članku je iznet stav koji od njih je najprihvatljiviji. Osim toga, u članku su obrađena pravila koja pokazuju da preduzetnike u sportu karakterišu određene posebnosti, a odnose se na: moguće pojmovno određenje preduzetnika u sportu i bitne elemente, koji čine taj pojam; delatnosti koje mogu da obavlaju sportski preduzetnici i uslove koje u vezi sa tim moraju da ispune; evidenciju i registraciju sportskih preduzetnika.

Ključne reči: preduzetnik u sportu, fizičko lice, delatnost, registracija, uslov

\section{UVODNE NAPOMENE}

Pravno istorijski posmatrano individualno preduzetništvo prethodi tzv. kolektivnom preduzetništvu, ${ }^{1}$ koje se ostvaruje u okviru različitih oblika, odnosno formi organizovanja. Od početka pa do danas samostalno obavljanje delatnosti od strane fizičkih lica je najpisutniji način poslovanja. ${ }^{2}$ Razlozi za to su višestruki: minimum formalnosti i niski troškovi za pokretanja posla, kao i za njegovo obustavljanje; o organizaciji, upravljanju i kontroli poslovanja, kao i o ostvarenim prihodima odlučuje isključivo preduzetnik. ${ }^{3}$ Otuda ne čudi da se i u sportskoj regulativi posvećuje pažnja preduzetništvu.

1 U teorji se s obzirom na broj lica koja učestvuju u registrovanju delatnosti, preduzetništvo deli na individualno i kolektivno (korporativno). O tome: Dabić, Lj., Individualni preduzetnik kao privredni subjekt i kao poseban pravnoorganizacioni oblik, Pravo i privreda, br. 5-8/05, str. 166.

2 U jednom periodu, posle II svetskog rata, zbog negiranja tržišta i slobode preduzetništva, preduzetnici su isčezli iz privrednog života. Sa oživljavanjem tržišnog modela privređivanja preduzetništvo je ponovo oživelo, što je imalo za posledicu da u Srbiji (podatak objavljen početkom 2019. godine) ima registrovanih 257.629 preduzetnika, a privrednih društava 134.067. Videti: https://www.ekapija.com/news/2389435/u2018-broj-firmi-u-srbiji-povecan-za-20000-izbrisano-za-1000.

3 O tome: Marković, V., Individualni preduzetnik, Beograd, 2016, str. 33; Milosavljević, M., Preduzetnik - subjekt uslužnih poslova u Republici Srbiji, Zbornik: Uslužni poslovi, Kragujevac, 2014, str. 1030. 
Opšta pravila kojima se reguliše nastanak, okvir za poslovanje i gubitak svojstva preduzetnika sadržana su u Zakonu o privrednim društvima, ${ }^{4} \mathrm{i}$ ona se primenjuju i na samostalno obavljanje sportske delatnosti, osim ako u propisima kojima se reguliše sport nije drukčije određeno. ${ }^{5}$ Broj tih posebnih odrednica se, posmatrano od Zakona o sportu RS iz 1996. godine, ${ }^{6}$ značajno povećao, što ukazuje da se sportskom preduzetništvu pridaje sve veći značaj.

U važećem Zakonu o sportu $\mathrm{RS}^{7}$ pravila o preduzetnicima u sportu nalaze se u delu koji je naslovljen „organizacije u oblasti sporta“, pri čemu se pod navedeni izraz podvodi svako pravno lice i preduzetnik koje se bavi organizovanjem sportskih aktivnosti i obavljanjem sportskih delatnosti u skladu sa zakonom (čl. 3. st. 1. tač. 15. ZOS). Ovakva odrednica, koje nije bilo u našim ranijim propisima, teško da se može prihvatiti. Preduzetnik ne može da se poistoveti sa bilo kakvom organizacijom, ${ }^{8}$ zato što su u njemu objedinjene i svojinske i upravljačke i preduzetničke funkcije. ${ }^{9}$ Otuda, prihvatljivija su rešenja, u pogledu određenja mesta za pravila o sportskim preduzetnicima, koja su izražena u Zakonu o sportu Republike Hrvatske ${ }^{10}$ (pravila o preduzetnicima, odnosno osobama koje samostalno obavljaju sportsku delatnost nalaze se u delu koji se odnosi na sportske delatnosti, gde se reguliše ko može da ih obavlja) i Zakonu o sportu Republike Crne Gore (pravila o preduzetnicima su svrstana u deo III - sportski subjekti, odeljak - fizička lica u sportu). ${ }^{11}$ Ipak, čini se da bilo najbolje kada bi se pravila o preduzetnicima u sportu izdvojila u poseban deo zakona, jer preduzetnici nisu samo fizička lica ili lica koja obavljaju određene delatnosti, već oni moraju da zadovolje i neke druge elemente, bez kojih se ne može govoriti o preduzetnicima.

Uzimajući u obzir važeća pravila o sportskim preduzetnicima, u članku će najpre biti posvećena pažnja terminološkom pitanju - koji je to termin koji treba koristiti za označenje lica koje samostalno obavlja neku sportsku delatnost, zatim pojmovnom određenju i konstitutivnim elementima, bez kojih nema preduzetnika, delatnostima koje mogu da obavlaju sportski preduzetnici i uslovima koje u vezi sa tim moraju da ispune, i na kraju evidenciji i registraciji sportskih preduzetnika.

4 Videti: čl. 83 - 92. Zakona o privrednim društvima Republike Srbije (Sl. glasnik RS, br. 36/11, 99/11, 83/14 - dr. zakon, 5/15, 44/18, 95/18, 91/19). U daljem tekstu: ZPD.

5 Čl. 93. st. 3. Zakona o sportu (Sl. glasnik Republike Srbije, br. 10/16).

6 Sl. glasnik RS, br. 52/96, 101/05.

7 Sl. glasnik RS, br. 10/16. U daljem tekstu ZOS.

8 Reč „organizacija“ označava spajanje delova (organa) u celinu, tako da ta celina bude sposobna za život, a takve organizacije su društva, udruženja ili ustanove. O tome: Vujaklija, M., Leksikon stranih reči i izraza, Beograd, 1975, str. 651.

9 Dabić, Lj., nav. članak, str. 166.

10 Narodne novine, br. 71/06, 150/08, 124/10, 124/11, 86/12, 94/13, 85/15, 19/16, 98/19.

11 S1. list Crne Gore, br. 44/18. 


\section{TERMINOLOŠKA PITANJA}

U teoriji su često vođene rasprave o tome kako treba nazvati fizičko lice koje se bavi privređivanjem. Ta diskusija je podstaknuta time što se u zakonodavstvima pojedinih zemalja koriste (ili su se koristili) različiti termini za označenje ovog lica. Možda je najbolji primer za tu različitost Republika Srbija, gde se od Zakona o ličnom radu pa do važećeg Zakona o privrednim društvima koriste termini radni čovek, privatni preduzetnik i preduzetnik. U drugim zakonodavstvima govori se o trgovcima, individualnim trgovcima, trgovcima pojedincima, samostalnim preduzetnicima pojedincima, individualnim preduzetnicima. ${ }^{12}$ Imajući u vidu napred navedene termine pojedini autori ističu da naziv preduzetnik treba preimenovati $u$ „,individualni privrednik“, zato što naziv preduzetnik ima i drugo značenje, posebno u ekonomiji (upotrebljava se radi označavanja lica koja obavljaju menadžerske poslove).$^{13}$ Drugi autori smatraju da za fizičko lice koje privređuje treba koristiti termin ,,individualni trgovac“, jer se taj termin koristi u uporednom pravu. ${ }^{14}$ Treći smatraju da bi u cilju otklanjanja sumnji o kakvom se licu radi trebalo koristiti termin ,,individualni preduzetnik“ ili ,preduzetnik pojedinac“. ${ }^{15}$ Četvrti smatraju da su termini ,individualni trgovac“ i ,preduzetnik“ sinonimi, odnosno da između njih nema sadržinskih razlika. ${ }^{16}$

U suštini posmatrano, u različitim propisima se za označenje fizičkog lica koje privređuje koriste dva termina: trgovac i preduzetnik, uz određene atribute (dodatke). Prvi termin je nastao u vreme kada su pojedinci mogli da se bave privrednim aktivnostima samo ako su imali status trgovaca (sticali su ga učlanjenjem u određena strukovna udruženja). Isti termin je zadržan i nakon što je donet tzv. Alarov dekret 1791. godine, kojim je promovisano načelo privrednog liberalizma, data sloboda bavljenja i izbora privrednih aktivnosti, omogućeno svakom zainteresovanom licu da može da se bavi privrednim aktivnostima u skladu sa određenim propisima. ${ }^{17}$ Ako se navedeno ima u vidu, čini se da termin koji ima veću širinu, koji je prikladniji za korišćenje povodom različitih aktivnosti, uključujući i sportske (ili one koje su vezane za sport) jeste drugi termin, a to je preduzetnik. Taj termin se koristi u ZOS RS (čl. 3, 14, 65, 66, 93-95) i ZOS CG (čl. 32, 33). Međutim, u ZOS RH umesto termina preduzetnik koristi se opisna fraza: ,lice koje samostalno obavlja sportsku delatnost“" (čl. 6, 8, 19). Razlog tome je činjenica da je u zakonodavstvu iskazano opredeljenje da se za fizičko lice koje samostalno privređuje koristi termin „trgovac pojedinac““ ${ }^{18}$ Kako se tim terminom evidentno ne može na odgovarajući

12 O tome: Spirović Jovanović, L., Trgovac pojedinac, preduzetnik ili individualni privrednik, Pravni život, br. 11/96, str. 149; Marković, V., nav. delo, str. 26-29; Dabić, Lj., nav. članak, str. 169.

13 O tome: Spirović Jovanović, L., nav. članak, str. 150.

14 Milenović, D., Preduzetnik (individualni trgovac) u našem pravu, Pravni život, br. 11/02, str. 81.

15 Dabić, Lj., nav. članak, str. 171.

6 Vasiljević, M., Vodič za čitanje Zakona o privrednim društvima, Beograd, 2004, str. 115.

17 Mićović, M., Ograničenje privredne inicijativnosti i načelo pravne sigurnosti u Zakonu o preduzećima, Pravo i privreda, br. 1 - 4/94, str. 110.

18 Videti čl. 611, 630. ZPD RH. 
način pokriti sportsko polje, to je prihvaćena (kao neka vrste iznuđenog rešenja) napred navedena opisna odrednica.

\section{POJAM SPORTSKOG PREDUZETNIKA I NJEGOVI BITNI ELEMENTI}

U propisima kojima se uređuje sport nije određen pojam sportskog preduzetnika, što znači da se isti može odrediti uz pomoć opšte odrednice o preduzetnicima, koja je sadržana u ZPD. ${ }^{19}$ Ako se uzmu u obzir određene posebnosti, koje proističu iz ZOS i karakterišu poslovanje sportskih preduzetnika, može se reći da je sportski preduzetnik poslovno sposobno fizičko lice koje obavlja određenu sportsku aktivnost i delatnost u cilju ostvarivanja prihoda i koje je kao takvo registrovano.

Iz ovako definisanog pojma sportskog preduzetnika proističe da ga čine četiri konstitutivna elementa: 1 . to je poslovno sposobno fizičko lice; 2 . predmet njegovog poslovanja mogu da budu zakonom određena sportska aktivnost i delatnosti; 3 . preduzetnik posluje u cilju sticanja prihoda; 4. preduzetnik se upisuje u registar. Povodom navedenog četvrtog elementa može se postaviti pitanje da li ga treba pominjati u okviru pojmovnog određenja sportskog preduzetnika, odnosno da li treba reći da se radi o konstitutivnom elementu. Ovo zato što registracija preduzetnika nema konstitutivno dejstvo u pogledu sticanja posebnog subjektiviteta, preduzetnik time ne stiče status pravnog lica. Bio registrovan ili ne, ${ }^{20}$ on odgovara za obaveze celokupnom svojom imovinom, dakle kako onom koju stiče povodom delatnosti koju obavlja, tako i svojom sopstvenom imovinom. ${ }^{21}$ Osim toga, zahtev za registracijom preduzetnika nije uvek istican, a ako jeste obaveza registracije je vezivana, na primer, za ostvareni nivo godišnjeg prometa. ${ }^{22} \mathrm{Na}$ kraju, i u komentarima pojma trgovca kao bitni elementi navode se samostalno obavljanje trgovačkih poslova i namera da se ostvare prihodi, ${ }^{23}$ a ne registracija.

Kada se radi o prvom, personalnom elementu, nesporno je da pokretač preduzetničkog poslovanja može da bude samo fizičko lice. Načelno, u skladu sa opšte usvojenim principom o slobodi privređivanja, to može da bude bilo koje lice. Ipak, ta sloboda nije apsolutna. Ona se ograničava tako što se postavljaju opšti i posebni uslovi, koji se moraju zadovoljiti ukoliko neko želi da ima status

19 Preduzetnik je poslovno sposobno fizičko lice koje obavlja delatnost u cilju ostvarivanja prihoda i koje je kao takvo registrovano u skladu sa zakonom o registraciji (čl. 83. st. 1. ZPD).

${ }^{20}$ Ako jedno ili više fizičkih lica ili pravno lice otpočne ili obavlja privrednu djelatnost, a ne registruje se smatra se preduzetnikom ili ortaklukom u odnosu prema trećim licima (čl. 2. st. 2. ZPD Crne Gore).

21 Imovinu fizičkog lica, koje je preduzetnik, opterećuju obaveze koje je ono preuzelo u vezi sa obavljanjem registrovane delatnosti, ali i obaveze koje su preuzete izvan nje - Rešenje Višeg trgovinskog suda, Pž. 9149/08 od 26. 12. 2008, Pravna praksa, br. 3/09, str. 70.

22 Marković, V., nav. čalank, str. 27; Dabić, Lj., nav. članak, str. 179.

23 Nije trgovac onaj ko u karitativne svrhe vrši poslove one vrste koji bi inače mogli biti trgovački. O ovome: Trgovački zakon za Kraljevinu Jugoslaviju, sa obrazloženjem Ministarstva pravde i registrom, Beograd, 1938, str. 3. 
preduzetnika. Opšti uslovi se primenjuju jednako na sva lica, a posebni se razlikuju i zavise od aktivnosti (delatnosti) koju neko želi da obavlja kao sportski preduzetnik.

Radi zaštite onih koji žele da se pojave kao nosioci poslovanja, ali i onih koji stupaju u odnos sa takvim osobama neophodno je da budu zadovoljeni opšti uslovi, a to znači da potencijalni nosioci poslovanja moraju da imaju sposobnost, kapacitet za poslovanje, kao i da ne podležu određenim zabranama koje su posledica kazni koje su im izrečene. ${ }^{24}$ Smatra se da jedno lice nema potreban kapacitet, sposobnost za poslovanje, što znači da ne može da stekne status preduzetnika, ako nije punoletno. Zato se i kaže da je preduzetnik poslovno sposobno fizičko lice. Nesposobnost za poslovanje, po pravilu, ne može da se otkloni primenom pravila građanskog prava o emancipaciji. Ipak, u poslednje vreme primetna su rešenja kojima se odstupa od navedenog pravila. Tako, na primer, $\mathrm{u}$ francuskom Trgovačkom zakonu je usvojeno pravilo prema kome emancipovani maloletnik može da bude trgovac sa ovlašćenjem organa starateljstva i odluke redovnog suda, ako podnese zahtev nakon što je emancipovan (čl. $121-2$ ). ${ }^{25}$ Takođe, i hrvatski ZOS propisuje da fizičke osobe mogu da samostalno obavljaju sportsku delatnost učestvovanja u sportskom takmičenju sa navršenih šesnaest godina (čl. 22. st. 3), čime se u potpunosti odbacuje tradicionalno pravilo o poslovnoj sposobnosti kao uslovu za obavljanje neke poslovne aktivnosti.

U cilju zaštite učesnika u privrednom prometu, ali i opšteg interesa, zabranjuje se licima, u odnosu na koja su izrečene određene mere (pravnosnažnom presudom, izvršnom odlukom nadležnog organa ili suda časti komore izrečena mera zabrane obavljanja delatnosti; izrečena osuda za krivično delo protiv privrede), da se u određenom vremenskom intervalu bave ili da nastave da se bave privrednim aktivnostima. Ograničenje za obavljanje preduzetničkih poslova može da proistekne i iz statusa koje jedno lice ima. ${ }^{26}$

\section{DELATNOSTI I USLOVI ZA NJIHOVO OBAVLJANJE}

Predmet poslovanja sportskog preduzetnika mogu da budu samo delatnosti koje su zakonom određene. U vezi sa tim rešenje iz ZOS RS izlazi izvan okvira uobičajenog i to zato što se pored delatnosti, kao predmet poslovanja sportskog preduzetnika navodi i sportska aktivnost. ${ }^{27} \mathrm{~S}$ obzirom da je delatnost jedno od individualnih obeležja povodom koga se vodi jedinstvena evidencija i sprovodi upis u registar, pri čemu se nigde ne spominje aktivnost kao podatak koji se registruje ili evidentira, to bi trebalo zakonski tekst izmeniti i aktivnost preimenovati u odgovarajuću vrstu sportske delatnosti. S tim u vezi, kao putokaz može da posluži pristup iskazan u ZOS RH gde je određeno da su sportske delatnosti: sudelovanje

24 O tome: Ripert, G., Roblot, R., Traité de droit commercial, t. 1, Paris, 1998, str. 169.

25 Prema čl. 36. Ordonanse br. 2019-964, ovo pravilo se primenjuje od 1. januara 2020. godine.

26 Ripert, G., Roblot, R., nav. delo, str. 173; videti: čl. 75, 91. ZPD.

27 Sportske aktivnosti jesu svi oblici fizičke i umne aktivnosti koji, kroz neorganizovano ili organizovano učešće, imaju za cilj izražavanje ili poboljšanje fizičke spremnosti i duhovnog blagostanja, stvaranje društvenih odnosa ili postizanje rezultata na takmičenjima svih nivoa (čl. 3. st. 1. tač. 1. ZOS). 
u sportskom takmičenju; sportska priprema, sportska rekreacija, sportska obuka, organizovanje i vođenje sportskog takmičenja, upravljanje i održavanje sportske građevine (čl. 18).

Prema ZOS RS sledeće sportske aktivnosti i delatnosti mogu da se obavljaju od strane sportskih preduzetnika, odnosno lica koja samostalno obavljaju sportske delatnosti (aktivnosti): profesionalno bavljenje sportskim aktivnostima u individualnim sportovima od strane lica koja imaju status vrhunskog sportiste (za obavljanje ove aktivnosti nisu potrebni poseban prostor, oprema i kadrovi) (čl. 14); ${ }^{28}$ sportsko posredovanje (čl. 94); pružanje usluga stručnog rada u sportu (čl. 95). ${ }^{29} \mathrm{U}$ Republici Hrvatskoj se sportsko posredovanje ne prepoznaje kao sportska delatnost, tako da status sportskog preduzetnika mogu da imaju kategorisani sportisti koji obavljaju sportsku delatnost učestvovanja u sportskom takmičenju, kao i osobe koje obavljaju delatnosti sportske pripreme, rekreacije i obuke (čl. 22. ZOS). U Crnoj Gori staus preduzetnika u sportu može da ima trener (čl. 32) i sportski stručnjak osposobljen za rad u sportu (čl. 33).

Prema ZOS preduzetničkim poslovima pružanja usluga stručnog rada u sportu (čl. 95), uključujući i sportsko posredovanje (čl. 94) može da obavlja lice koje ispunjava uslove predviđene zakonom ${ }^{30}$ i poseduje dozvolu za rad. S obzirom da se zahteva dozvola za rad, to znači da je u pogledu obavljanja stručnog rada u sportu usvojen sistem autorizacije ili licenciranja, čime se ostvaruje kontrola pristupa

28 Profesionalni sportista jeste sportista koji se bavi sportskom aktivnošću kao jedinim ili osnovnim zanimanjem (čl. 3. st. 1. tač. 9. ZOS). Zvanje u okviru zanimanja profesionalni sportista jeste profesionalni sportista. Uslov osposobljenosti za razvrstavanje u zvanje jeste najmanje osnovno obrazovanje (čl. 64. i 65. Pravilnika o nomenklaturi sportskih zanimanja i zvanja, Sl. glasnik RS, br. 7/13).

29 Stručni rad u sportu obuhvata: planiranje i sprovođenje sportskih aktivnosti dece i omladine, rekreacije građana, treninga sportista, sportskog vaspitanja, obučavanja i sportskog usavršavanja, kineziterapijskog vežbanja; vođenje sportista na takmičenjima; kontrolu psihofizičkih i funkcionalnih sposobnosti učesnika u sportskim aktivnostima; istraživačko-razvojni i naučnoistraživački rad u sportu; stručno-savetodavni i stručno-informativni rad; planiranje sportskih programa i projekata; dokumentovanje sportske stručne literature, pripremanje i uređivanje sekundarnih informacionih izvora u sportu; kreiranje, planiranje i organizovanje propagandnih kampanja i akcija, odnosa sa javnošću i kontakata sa sredstvima javnog informisanja u sportu; izveštavanje sa sportskih priredaba, pisanje informativnih i analitičkih novinskih članaka u oblasti sporta; planiranje i sprovođenje sportskih priredaba; posredovanje u sportskim transferima; sportski menadžment i organizovanje sportskog poslovanja; sportsko suđenje; staranje o bezbednosti, redu i sigurnosti na sportskim priredbama i u sportskim objektima i o sprečavanju dopinga u sportu; staranje o zdravstvenom stanju sportista (čl. 27. st. 1. ZOS).

30 Preduzetnik može obavljati sportsku delatnost (ministar propisuje uslove) ako ima obezbeđen odgovarajući objekat, odgovarajuću opremu, angažovane odgovarajuće sportske stručnjake i ako ispunjava uslove u pogledu bezbednosti u obavljanju delatnosti, uključujući i potrebne akte (pravila o redu i sl.), ako zakonom nije drukčije utvrđeno (čl. 93. st. 2 i 3). 
obavljanju stručnog rada. ${ }^{31}$ Ovaj sistem je prihvaćen i u Crnoj Gori, ${ }^{32}$ ali ne i u Republici Hrvatskoj. ${ }^{33}$

Postupak i bliži uslovi za izdavanje dozvole za rad sportskom stručnjaku uređuju se sportskim pravilima nadležnog nacionalnog sportskog saveza. Dozvola za rad se izdaje na osnovu podnetog zahteva i provere veština i znanja kandidata koji podnosi zahtev.

Stučnjaku se izdaje dozvola: 1) ako ispunjava uslove u pogledu stručne spreme ili stručne osposobljenosti, odnosno ako ima odgovarajuće sportsko zvanje, u skladu sa Zakonom i propisima kojima se uređuje nomenklatura sportskih zanimanja i zvanja; 2) ako je registrovan kod odgovarajućeg nacionalnog granskog sportskog saveza, odnosno ako je član stručnog sportskog udruženja koje je u sastavu nacionalnog granskog sportskog saveza; 3) ako je zdravstveno sposoban za obavljanje stručnog rada u sportu, u skladu sa sportskim pravilima nadležnog nacionalnog granskog sportskog saveza; 4) ako je od perioda sticanja prethodne dozvole za rad obavio profesionalnu praksu (praktičan rad) u trajanju od najmanje 90 sati, u skladu sa sportskim pravilima nadležnog nacionalnog granskog sportskog saveza; 5) ako ima odgovarajuće radno ili sportsko (takmičarsko) iskustvo, u skladu sa sportskim pravilima nadležnog nacionalnog granskog sportskog saveza; 6) ako je obavio stručno usavršavanje u skladu sa sportskim pravilima nadležnog nacionalnog granskog sportskog saveza; 7) ako sportskom stručnjaku nije zabranjeno obavljanje stručnog rada u sportu za period važenja dozvole za rad; 8) ako ima postignute odgovarajuće sportske rezultate, u skladu sa sportskim pravilima nadležnog nacionalnog granskog sportskog saveza; 9) ako uplati naknadu za troškove izdavanja dozvole za rad (čl. 5. Pravilnika o dozvoli za rad sportskih stručnjaka). ${ }^{34}$

31 Uporedno-pravno posmatrano, pored sistema licenciranja postoji i sistem deklaracije, koji podrazumeva automatsku registraciju kod nadležnog sportskog saveza svakog lica koje podnese zahtev $\mathrm{i}$ potrebna dokumenta. Ne zahteva se bilo kakva provera znanja lica koje želi da se bavi stručnim radom u sportu. Prema ovom sistemu, težište nije na kontroli pristupa obavljanju stručnih poslova već na kontroli vršenja tih poslova. Sistem registrovanja prihvaćen je u Pravilniku FIFA o radu sa posrednicima (stupio na snagu 1. 4. 2015. godine), čime je napušten sistem licenciranja, koji je važio 24 godine. O tome: Vuković, Z., Ugovori o stručnom angažovanju sportskih stručnjaka, dok. teza, Kragujevac, 2019, str. 109, 195.

32 Videti: čl. 32. i 33. ZOS CG.

33 U ZOS RH je određeno da fizičke osobe mogu samostalno obavljati sportske delatnosti: sportske pripreme, sportske rekreacije i sportske oduke ako imaju opštu, a po potrebi i posebnu zdravstvenu sposobnost, i odgovarajuću stručnu spremu; učestvovanja u sportskim takmičenjima ako imaju: opštu, a po potrebi i posebnu zdravstvenu sposobnost, navršenih šesnaest godina, status kategorizovanog sportiste $\mathrm{i}$ ispunjavaju posebne uslove prema pravilima odgovarajućeg nacionalnog sportskog saveza (čl. 22. st. 2. i 3. ZOS). U čl. 9. je izvršena maksimalna liberalizacija zahteva koji se odnose na stručnu spremu osoba koje sprovode sportske pripreme, rekreaciju i oduku. Određeno je da to može da bude lice koje ima stručnu spremu najmanje na nivou trenera prvostupnika (završio stručne studije za obuku trenera u trajanju od tri godine), s tim što te poslove može obavljati i osoba: koja je osposobljena putem ustanove za osposobljavanje kadra na osnovu programa za sticanje licenci krovnih svetskih ili evropskih udruženja određenog sporta; koja je osvojila medalju na olimpijskim igrama, svetskom ili evropskom seniorskom prvenstvu, a stručno je osposobljena putem ustanove za osposobljavanje kadra u sportu; koja je poslove trenera obavljala najmanje 15 godina do dana stupanja na snagu Zakona, a stručno je osposobljena putem ustanove za osposobljavanje kadra u sportu.

34 Sl. glasnik RS, br. 7/13. 
O izadavanju dozvole nadležni nacionalni granski sportski savez obaveštava Ministarstvo, u roku od 15 dana od dana izdavanja, i vrši javnu objavu izdatih dozvola na zvaničnom sajtu saveza (čl. 94. st. 5. i 6. ZOS).

\section{REGISTRACIJA I EVIDENCIJA SPORTSKIH PREDUZETNIKA}

Postupak registracije pokreće se podnošenjem registracione prijave ${ }^{35}$ Agenciji za privredne registre. Podnosilac registracione prijave može biti: fizičko lice preduzetnik ili lice koje punomoćjem ovlasti preduzetnik (ukoliko punomoćje za podnošenje registracione prijave preduzetnik daje licu koje nije advokat, njegov potpis kao vlastodavca mora biti overen od strane organa nadležnog za overu potpisa, a ako se daje advokatu, potpis vlastodavca ne mora biti overen).

U prijavu za upis u Registar i dokumentaciju ${ }^{36}$ koja se uz prijavu prilaže unose se odgovarajući podaci iz čl. 5. st. 10. ZOS (podaci o ličnosti - ime, ime roditelja i prezime; datum i mesto rođenja; stručni/akademski naziv; sportsko zvanje; naziv i nivo dozvole za rad; datum položenog stručnog/završnog ispita i postignut uspeh na ispitu, odnosno ukupna prosečna ocena; fotografija; ocena zdravstvene sposobnosti za bavljenje sportskim aktivnostima i stručnim radom u sportu; sportski rang prema odgovarajućoj nacionalnoj kategorizaciji; podaci za kontakt; broj isprave koja služi za identifikaciju lica) (čl. 65. st. 9. ZOS). ${ }^{37}$

Registrator prilikom registracije preduzetnika ne proverava i ne traži dokaze o ispunjenosti uslova za obavljanje sportskih delatnosti predviđenih zakonom i bliže propisanih od strane nadležnog ministra jer proveru vrši sportski inspektor u postupku redovnog inspekcijskog nadzora (čl. 93. st. 5. ZOS).

Registrator rešenjem odlučuje o prijavi u roku od pet radnih dana od dana prijema prijave (čl. 15. st.1. Zakona o postupku registracije u Agenciji za privredne registre). ${ }^{38}$ Ako su ispunjeni uslovi za registraciju, registrator bez učešća podnosioca

35 Pravna priroda ovog akta je dvojaka: po svojoj formi predstavlja istovremeno izjavu volje kojom se pokreće upravni postupak (procesni akt), ali i izjavu volje usmerene na osnivanje (materijalni akt). $\mathrm{O}$ tome: Marković, V., nav. delo, str. 79.

36 Dokumentacija koja se prilaže uz prijvu osnivanja preduzetnika prilaže se sledeća dokumentacija (dokaz o identitetu preduzetnika - fotokopija lične karte; ukoliko se preduzetnik registruje za obavljanje delatnosti za koju se traži prethodna dozvola, kao uslov za registraciju, potrebno je dostaviti i odgovarajuću dozvolu u originalu ili overenoj kopiji; pisano ovlašćenje kojim preduzetnik izdaje prokuru, ukoliko je izdata prokura; dokaz o uplati naknade.

37 Prema obrascu o jedinstvenoj registracionoj prijavi osnivanja preduzetnika, prijava sadrži sledeće podatke: poslovno ime, naziv, sedište, skraćeno poslovno ime (upisuje se ako postoji naziv), kontakt podaci preduzetnika, početak obavljanja delatnosti (preduzetnik može da otpočne sa obavljanjem delatnosti kada obezbedi odgovarajući prostor, opremu i kadrove, odnosno dužan je da pre početka obavljanja delatnosti pribavi akt nadležnog organa o ispunjenosti propisanih uslova u pogledu prostora, opreme i kadra, ukoliko je to predviđeno), pretežna delatnost, adresa za prijem pošte, adresa za prijem elektronske pošte, kontakt podaci za poresku upravu, lični podaci preduzetnika za fond PIO, izdvojena mesta obavljanja delatnosti. Videti: https://www.apr.gov.rs/.

38 Sl. glasnik RS, br. 99/11, 83/14, 31/19. U daljem tekstu: ZOR. 
prijave u postupku, donosi rešenje kojim usvaja prijavu (čl. 16. ZOR). Registrovani podaci i dokumenti istovremeno se objavljuju sa donošenjem rešenja kojim se prijava usvaja. Registracija proizvodi pravno dejstvo prema trećim licima narednog dana od dana objavljivanja (čl.22. ZOR).

Nakon završene registracije započinje postupak evidentiranja preduzetnika tako što Agencija dostavlja Ministarstvu bez odlaganja sve registrovane podatke o preduzetnicima u oblasti sporta putem web servisa radi upisa u jedinstvenu nacionalnu evidenciju (čl. 66. ZOS) preduzetnika. ${ }^{39}$ Evidenecija predstavlja nezavisni informaciono-dokumentacioni sistem koji ne treba poistovećivati sa poslovima koje obavlja Agencija za privredne registre. Njeno uvođenje se opravdava potrebom organizovanog i sistematskog praćenja stanja u sportu, pri čemu je na osnovu upisanih podataka (oni su detaljniji od onih koji se upisuju pri registraciji), moguće da se ostvari dugoročno, strateško, planiranje njegovog razvoja.

Preduzetnci u oblasti sporta dužni su da podnesu prijavu za upis u nacionalnu evidenciju najkasnije do kraja februara tekuće godine za prethodnu godinu, a promena podataka mora da se prijavi u roku od 30 dana od nastanka promene. (čl. 168. st. 8. i 9. ZOS). Ako preduzetnik ne podnese prijavu ili ako dostavi netačne podatke kazniće se za prekršaj novčanom kaznom u iznosu od 50.000 do 250.000 dinara (čl. 176. st. 3. ZOS). ${ }^{40}$

U nacionalnu evidenciju preduzetnika u sportu upisuju se sledeći podaci: 1) broj upisa; 2) identifikacija preduzetnika: (1) ime i prezime, odnosno naziv (pun i skraćen), (2) sedište (opština, mesto, ulica i broj), (3) jedinstveni matični broj građana, (4) matični statistički broj, (5) žiro račun (broj i kod koga se vodi), (6) PIB broj, (7) broj telefona, (8) internet prezentacija, (9) imejl adresa, (10) stručno, odnosno akademsko zvanje, (11) sportsko zvanje; 3) status: (1) profesionalni sportista, (2) preduzetnik koji se bavi obavljanjem sportske delatnosti, (3) upis u registar (organ kod koga je izvršen upis, broj registra, broj i datum rešenja o upisu), (4) brisanje iz registra (broj i datum rešenja o brisanju iz nadležnog registra), (5) broj dozvole za rad i od koga je izdata; 4) sportske aktivnosti i delatnosti: (1) sportske aktivnosti, (2) registrovane sportske delatnosti (naziv i šifra delatnosti), (3) područje delatnosti, (4) način obavljanja sportskih delatnosti (lično ili preko angažovanih

39 Nacionalna evidencija o preduzetnicima u sportu je jedna od devet, koje se vode u Zavodu za sport i medicinu sporta RS. Videti: čl. 2. Pravilnika o nacionalnim evidencijama u oblasti sporta, Sl. glasnik RS, br. 24/17). U daljem tekstu: Pravilnik.

40 Upisom u evidenciju od značaja je za: korišćenje budžetskih sredstava za gradnju i adaptaciju sportskih objekata, korišćenje budžetskih sredstava za posebne programe od interesa za JLS, dobijanje saglasnosti za organizovanje velikih međunarodnih takmičenja, ostvarivanje saradnje sa Ministarstvom omladine i sporta, Zavodom za sport, Olimpijskim komitetom Srbije na realizaciji redovnih i posebnih programa, ali i da se izbegnu kaznene mere određene Zakonom o sportu. Videti: http://www.rzsport.gov. rs/. 
lica), (5) vrsta stručnog rada u sportu, (6) takmičenja u kojima učestvuje (naziv i rang) (čl. 4. Pravilnika). ${ }^{41}$

\section{ZAKLJUČAK}

Preduzetnicima, a posebno preduzetnicima u sportu, teorija ne pridaje nikakav značaj. Zbog odsustva teorijske misli u ovoj sferi poslovanja vidljivo je, s jedne strane, da propisi koji se donose nisu rezultat neke ozbiljnije analize, i, s druge strane, da se rešenja koja su usvojena u pojedinim zemljama, povodom preduzetnika u sportu, u značajnoj meri razlikuju. Te razlike su i terminološke, strukturne i suštinske. Tako, u vezi sa ovom kategorijom privrednih subjekata koriste se različiti termini, a najčešće trgovac i preduzetnik. Ako se ima u vidu da je prvi termin nastao u vreme kada su pojedinci mogli da se bave privrednim aktivnostima samo ako su imali status trgovaca, kao i da bi bilo potpuno neadekvatno nazvati nosioca sportske delatnosti trgovcem, jasno je da je termin preduzetnik naziv koji treba koristiti za označenje ovih lica. Strukturne razlike se očituju u tome što se pravila o preduzetnicima u sportu smeštaju u potpuno različite zakonske odeljke. U RS se mogu naći među pravilima o sportskim organizacijama, jer se preduzetnici tretiraju kao vid organizacije u sportu. U RH, pravila o preduzetnicima se mogu naći u delu koji se odnosi na sportske delatnosti, gde se reguliše ko može da ih obavlja, dok su u CG pravila o preduzetnicima svrstana u deo o sportskim subjektima, odeljak fizička lica u sportu. Čini se da bi bilo najbolje kada bi se pravila o preduzetnicima u sportu izdvojila u poseban deo zakona, zato što predstavljaju posebnu vrstu privrednih subjekata, koja se ne može svrstati među neke druge poznate organizacione oblike. Suštinske razlike se tiču delatnosti koje mogu da obavljaju preduzetnici u sportu, uslova pod kojima oni to mogu da čine i, na kraju, registracije i evidentiranja sportskih preduzetnika. Kada se radi o delatnostima, za razliku od RH i CG, samo RS prepoznaje posredovanje ka sportsku delatnost. U vezi sa obavljanjem sportskih delatnosti od strane peduzetnika u RS i CG prihvaćen je sistem licenciranja (preduzetničke poslovie može da obavlja lice koje ispunjava uslove predviđene zakonom i poseduje dozvolu za rad), a u RH sistem deklaracije (sistem koji podrazumeva automatsku registraciju kod nadležnog sportskog saveza svakog lica koje podnese zahtev i potrebna dokumenta; ne zahteva se bilo kakva provera znanja lica koje želi da se bavi stručnim radom u sportu). Kada se radi o registraciji, u RS registracija je centralizovana, a osim toga dodatno se zahteva i podnošenje prijave za upis u jedinstvenu nacionalnu evidenciju. $\mathrm{Na}$ osnovu navedenog može se izvesti opšti zaključak da je u RS usvojen prilično rigidan sistem, da bi bilo poželjno da pretrpi izmene u pravcu nalaženja mere između dva

${ }^{41}$ Za razliku od RS, i rešenja o registraciji i evidenciji, u RH nema evidencije, registracija preduzetnika nije centralizovana (fizičke osobe koje samostalno obavljaju sportsku delatnost upisuju se u registar koji vode nadležni uredi državne uprave u županiji odnosno Gradu Zagrebu prema prebivalištu fizičke osobe), s tim što se povodom preduzetnika upisuju samo podaci koji se tiču njegovog imena, prezimena, prebivališta i delatnosti koju obavlja. Videti: Pravilnik o registru športskih delatnosti, Narodne novine, br. 112/06). 
principa: principa pravne sigurnosti i slobode privređivanja. Osim toga, poželjne su i neke druge korekcije kojima bi se eliminisalo mešanje opštih i posebnih uslova za obavljanje preduzetničkih aktivnosti u sportu (ti uslovi nisu istog ranga, jer onaj ko ne ispunjava opšte uslove isključen je automatski iz kruga lica koja mogu da pretenduju na status preduzetnika) ili ostvarilo jasno pozicioniranje preduzetnika kao nosilaca određenih sportskih delatnosti.

\section{LITERATURA}

1. Dabić, Lj., "Individualni preduzetnik kao privredni subjekt i kao poseban pravnoorganizacioni oblik", Pravo i privreda, br. 5-8/05.

2. Marković, V., Individualni preduzetnik, Beograd, 2016.; Mićović, M., "Ograničenje privredne inicijativnosti i načelo pravne sigurnosti u Zakonu o preduzećima", Pravo i privreda, br. $1-4 / 94$.

3. Milenović, D., "Preduzetnik (individualni trgovac) u našem pravu", Pravni život, br. $11 / 02$.

4. Milosavljević, M., „Preduzetnik - subjekt uslužnih poslova u Republici Srbiji“, Zbornik: Uslužni poslovi, Kragujevac, 2014.

5. Ripert, G.; Roblot, R., Traité de droit commercial, t. 1, Paris, 1998.

6. Spirović Jovanović, L., „Trgovac pojedinac, preduzetnik ili individualni privrednik“, Pravni život, br. 11/96.

7. Vasiljević, M., Vodič za čitanje Zakona o privrednim društvima, Beograd, 2004.

8. Vujaklija, M., Leksikon stranih reči i izraza, Beograd, 1975.

9. Vuković, Z., Ugovori o stručnom angažovanju sportskih stručnjaka, dok. teza, Kragujevac, 2019.

1. https://www.ekapija.com/news/2389435/u-2018-broj-firmi-u-srbiji-povecan-za20000-izbrisano-za-1000.

2. https://www.apr.gov.rs/

3. http://www.rzsport.gov.rs/ 


\section{SPORTS ENTREPRENEURS}

Apart from legal entities, sports business operators may also be individuals, in the capacity of entrepreneurs. Author analyzes various terms used in comparative law and practice to designate these persons by pointing out the most preferrable solution. In addition, the article elaborates the specific rules that clearly differentiate sports entrepreneurs from other business operators. Those rules are particularly related to: possible conceptual designation of sports entrepreneurs and related constituent elements; business activities that can be performed by sports entrepreneurs and respective conditions that need to be fullfiled; records and registration of sports entrepreneurs.

Key words: sports entrepreneurs, natural person, business activity, registration, condition 